\title{
Pengaruh Penggunaan Software Zahir POSX Terhadap Manajemen Bisnis Usaha Mikro Kecil dan Menengah di Kota Samarinda
}

\author{
Martinus Robert Hutauruk \\ Dosen Universitas Widya Gama Mahakam Samarinda \\ Martinrioindra@yahoo.com \\ Agus Rudolf Rihi, Desna Reti, Nur Lutfy Hanif \\ Mahasiswa Universitas Widya Gama Mahakam Samarinda
}

\begin{abstract}
Abstrak
The development of information technology which is the impact to development revolution of industrial $4^{\text {th }}$ makes every activity inseparable from network usage with entrepreneurs in the Micro, Small and Medium Enterprises (UMKM) group, who also must be albe to capture the business opportunity.

The purpose of this study is to confirm the role of Zahir POSX software on business management in the UMKM group in Samarinda city. This research was conducted on 275 populations in the UMKM group located in Samarinda City, especially in the area around Mulawarman University and University of Widya Gama Mahakam Samarinda, and by using the Slovin method with a 5\% error rate, 163 respondents were taken as sample. Test on validity and reliability have been darried out with good results on the items received agin before further analysis.

This study was conducted in order to predict the role of Zahir POSX software on business Management and used the Structural Equation Modeling (SEM) wih multiple groups through Smart PLS Version 3.2.8 software.

The results of this study found that on use Zahir POSX software had a positive and significant impact on UMKM group in Samarinda. Entrepreneurs will be easier in controloing their business, even using paper less media. The results also show that through modern accounting software, it will increasingly make business management more effective and efficient.
\end{abstract}

Keywords: Accounting software, Zahir POSX, business management

\section{Pendahuluan}

Seiring dengan perkembangan teknologi, sistem akuntansi juga mengalami perkembangan sesuai dengan kebutuhan pelaku usaha. Jika sebelumnya pelaku usaha disibukkan dengan tugas membuat laporan keuangan dengan proses manual, sekarang proses manual sudah mulai ditinggalkan. Dengan semakin ketatnya persaingan bisnis mengakibatkan pelaku usaha dituntut untuk semakin responsif dalam menghadapi pasar serta meningkatkan produktivitasnya. Demi mendukung hal tersebut, salah satu langkah yang diambil pelaku usaha adalah dengan mengembangkan sistem akuntansi dengan menggunakan komputer.

Saat ini semakin marak berkembang bisnis atau usaha dalam skala Usaha Mikro Kecil dan Menengah (UMKM), baik di sector jasa, dagang dan manufaktur ringan. Hal ini didukung oleh karakteristik dari UMKM sendiri yang banyak memiliki kesesuaian dengan budaya masyarat yang ada di kota Samarinda. 
Selama ini kelompok pengusaha UMKM melakukan bisnisnya dengan hanya berbekal keberanian dan perkiraan serta dari pengalaman para pendahulunya saja atau tanpa melalui manajemen bisnis yang baik dan seharusnya, walaupun masih mendapatkan keuntungan, namun belum keuntungan yang secara optimal mampu dicapai. Karena mereka tidak pernah sedikitpun melakukan pencatatan atas bisnis mereka. Pada situasi ini diutamakan pada usaha jasa (laundry, pengantaran, barbershop, salon kecantikan, dll), usaha dagang (toko kelontong, dangan ikan, dagang sayur, dagang buah-buahan warung, dll), dan usaha manufaktur ringan (jual bakso, jual mie, jual soto, jual martabak/terang bulan, jual gorengan, jual nasi kuning, dll). Pedagang kecil biasanya kesulitan dalam menerapkan sistem informasi tentang penjualan tersebut. Kesulitan itu karena mahalnya pembangunan sistem informasi baik hardware dan software serta dibutuhkan juga petugas pengelola sistem informasi tersebut, sehingga malah menambah beban keuangan dari pedagang tersebut. Tetapi di sisi lain adanya sistem informasi sangat dibutuhkan oleh pedagang dalam rangka mengembangkan usahanya.

Selama ini perangkat lunak akuntansi tradisional umumnya dibeli sebagai produk dan iinstal pada desktop masing-masing pengguna. Namun saat ini dengan kemajuan teknologi, cloud accounting yang ditampilkan Zahir POSX mampu menyediakan layanan yang lebih baik dan dapat diakses melalui jaringan internet sehingga mampu memodernisasi seluruh lingkungan bisnis (Dimitru and Matei, 2015:665-671). Cloud accounting adalah sebagai salah satu pemanfaatan teknologi internet untuk membangun system komputeasi awan ditambah akuntansi dan membentuk sistem akuntansi awan (Zhang and Gu, 2013:140-142).

Smartphone bukan hanya menjadi alat komunikasi tetapi juga menjadi sebuah komputer mini yang dapat melakukan berbagai hal yang dibutuhkan manusia. Berbagai aplikasi untuk smartphone tersedia dengan ragam fitur dan kegunaannya. Salah satu aplikasi yang dapat digunakan untuk kebutuhan penjualan (kasir) adalah aplikasi point of sale (POS). Point of sale adalah aplikasi smartphone yang dapat melakukan pencatatan dan pegolahan data barang, jumlah dan harga barang, pembuatan laporan (reporting) serta berbagai transaksi yang terkait dengan proses penjualan. Terdapat banyak aplikasi point of sale yang tersedia saat ini dan salah satunya adalah Zahir POSX dan software ini akan ditawarkan kepada para pengusaha UMKM yang berada di Samarinda. Khususnya lokasi sekitar kampus Universitas Mulawarman dan Universitas Widya Gama Mahakan Samarinda.

\section{Kerangka Teoritis}

\subsection{Akuntansi}

Terdapat banyak definisi akuntansi yang dikemukakan, dan salah satunya adalah yang dikemukakan oleh American Institute of Certified Public Accountant (AICPA) pada tahun 1970 (Kartikahadi et al., 2012:3), yaitu: "Accounting is a service activity is to provide quantitative information, primarily financial in nature, about economic entities that is intentended to be useful in making economic decision in making reasoned among alternative course of action".

Pada uraian tersebut dijelaskan bahwa pengertian akuntansi sebagai suatu aitivitas kegiatan pelayanan yang fungsinya terutama untuk memberikan informasi kuantitatif, terutama bersifat keuangan, dari suatu entitas ekonomi dengan maksud berguna untuk pengambilan keputusan ekonomi, dalam memilih secara bijak di antara alternative tindakan. Bila kita memberikan rumusan pengeritan akuntansi berdasarkan pendekatan sistem, maka dapat dikatakan bahwa: "Akuntansi adalah suatu sistem informasi keuangan, yang bertujuan untuk menghasilkan dan melaporkan informasi yang relevan bagi berbagai pihak yang berkepentingan”. Hutauruk $(2017: 3 ; 2017: 4)$ mengemukakan bahwa akuntansi adalah merupakan kumpulan konsep dan teknik yang digunakan untuk mengukur dan melaporkan informasi keuangan dalam suatu unit usaha ekonomi. Sedangkan menurut American Accounting Association (1966) dikemukakan bahwa: "Akuntansi adalah proses mengenali, mengukur, dan mengkomunikasikan informasi ekonomi untuk memperoleh pertimbangan dan keputusan yang tepat oleh pemakai informasi yang bersangkutan". Dikemukakan pula oleh Horngren, Harison dan Suardy (2013) akuntansi adalah: "Suatu sistem 
informasi yang mengukur aktifitas bisnis, memproses data menjadi laporan dan mengkomunikasikan hasilnya kepada para pengambil keputusan”.

Berdasarkan dari berbagai pengertian tersebut maka dapat disimpulkan bahwa akuntansi adalah merupakan suatu aktifitas jasa yang berfungsi memberikan segala informasi yang bersifat kuantitatif dan bersifat ekonomi dan terutama yang bersifat keuangan serta bermanfaat sebagai informasi dalam mendukung pengambilan keputusan bisnis.

\subsection{Laporan Keuangan}

Menurut Ikatan Akuntan Indonesia (SAK-UKM 2010; bab 2), dikemukakan bahwa laporan keuangan adalah suatu penyajian sterstruktur dari posisi keuangan dan kinerja keuangan suatu entitas. Baridwan (2004:17) megemukakan bahwa laporan keuangan adalah ringkasan dari suatu proses pencatatan, merupakan suatu ringkatan transaksi-transaksi keuangan yang terjadai selama tahun buku yang bersangkutan. Kemudian Djarwanto (2010:5) mengemukakan bahwa laporan keuangan adalah merupakan hasil refleksi dari sekian banyak transaksi yang terjadi dalam suatu perusahaan. Selanjutnya menurut Machfoedz dan Mahmudi (2008:1.18) laporan keuangan adalah hasil akhir dari proses akuntansi. Porses akuntansi dimulai dari bukti transaksi, kemudian dicatat dalam harian yang disebut jurnal, kemudian secara periodic dari jurnal dikelompokkan ke dalam buku besar sesuai dengan transaksinya, dan tahap akhi dan proses akuntansi adalah penyusunan laporan keuangan.

Berdasarkan dari uraian tersebut maka dapat disimpulkan bahwa laporan keuangan adalah meupakan hasil tidakan pembuatan ringkasan data keuangan perusahaan. Laporan keuangan ini disusun dan ditafsirkan untuk kepentingan manajemen dan pihak-pihak lain yang menaruh perhatian atau mempunyai kepentingan dengan data keuangan peusahaan. Laporan keuangan yang disusun guna memberikan informasi kepada berbagai pihak adalah terdiri dari: Neraca, Laporan Laba Rugi, Laporan Perubahan Ekuitas, dan Laporan Arus Kas. Dalam hal ini, neraca menggambarkan kondisi keuangan darsi suatu perusahaan pada tanggal tertentu, umumnya pada akhir bulan atau tahun atau pada saat penutupan buku, dan neraca ini juga memuat aset, kewajiban dan ekuitas. Laporan laba rugi adalah memperlihatkan hasil yang diperoleh dari penjualan barang dan beban yang dikeluarkan sehubungan dengan aktivitas penjualan tersebut. Laporan perubahan ekuitas adalah laporan yang menunjukkan posisi ekuitas akhir perusahaan, termasuk ekuitas awal dan penambahan ekuitas dari laba perusahaan. Laporan arus kas adalah laporan yang menunjukkan pergerakkan uang tunai perusahaan yang berasal dari penerimaan dan pengeluaran dari kegiatan operasional, investasi dan pendanaan.

\subsection{Sistem Informasi}

Dunia teknologi selalu berkembang dan tidak akan pernah habis untuk dibahas. Dalam dunia teknologi dikenal banyak istilah yang kesemuanya berhubungan dengan teknologi dan informasi. Sebuah istilah yang sering digunakan dalam dunia teknologi dan informasi adalah sistem informasi. Dimana istilah ini sering disalahartikan penggunaannya. Menurut Gordon B Davis (1991:91) sistem informasi adalah suatu sistem yang menrima input atau masukan data dan instruksi, mengolah data sesuai dengan instruksi dan mengeluarkan hasilnya. Kemudian menurut pendapat John F. Nash (1995:8) dikemukakan bahwa sistem informasi adalah kombinasi dari manusia, fasilitas dan alat teknologi, media, prosedur dan pengendalian yang ditujukan untuk mengatur jaringan komunikasi yang penting, proses transaksi tertentu dan rutin, membantu manajemen dan pemakai internal dan eksternal dan menyediakan dasar untuk pengambilkan keputusan yang tepat. Menurut Rommey (2005:16) sistem informasi adalah cara untuk menyimpan, mengelola, mengendalikan dan melaporkan informasi dengan cara yang suatu organisasi dapat mencapai tujuan yang ditetapkan. 
Berdasarkan dari uraian tersebut, maka secara sederhana pengertian sistem informasi bisa didefinisikan sebagai sebuah sistem yang mana terdiri dari teknologi atau alat, media yang digunakan, prosedur yang terorganisir, serta sumber daya manusia yang didalamnya bekerja sebagai sebuah kombinasi membentuk sebuah sistem yang terorganisir. Kombinasi antara teknologi dan manusia ini bekerja untuk mendapatkan sebuah informasi yang kemudian digunakan untuk mendukung suatu manajemen guna mengambil sebuah kebijakan atau keputusan.

\subsection{Sistem Informasi Akuntansi}

Sistem informasi akuntansi sangat diperlukan oleh sebuah perusahaan yang bergerak dalam bidang apapun, karena mengandung sebuah proses untuk melaporkan kondisi keuangan perusahaan secara akurat dan benar untuk semua pihak yang membutuhkan. Proses tersebut berkaitan dengan teknologi informasi untuk memajukan usaha atau bisnis. Menurut Mulyadi (2001) sistem informasi akuntansi adalah organisasi formulir, catatan dan laporan yang dikorrdinasi sedemikian rupa untuk menyediakan informasi keuangan yang dibutuhkan oleh manajemen guna memudahkan pengelolaan perusahaan. Sedangkan menurut Widjajanto (2001) sistem informasi akuntansi adalah susunan formulir, catatan, peralatan termasuk komputer dan perlengkapannya srta alat komunikasi, tenaga perlaksanaannya dan laporan yang terkoordinasi secara erat yang didesain untuk mentransformasikan data keuangan menjadi informasi yang dibutuhkan manajemen.

Berdasarkan dari uraian tersebut maka dapat disimpulkan bahwa Sistem Informasi Akuntansi (SIA) adalah merupakan suatu sistem yang terdiri dari berbagai formulir, catatan dan laporan yang telah disusun dan menghasilkan suatu informasi keuangan yang dibutuhkan oleh perusahaan. Dengan demikian manajemen perusahaan dapat melihat keuangan degnan jelas melalui sistem tersebut, dan selain itu manajemen juga dapat mengontrol kinerja dari sistem yang digunakan dan kinerja bisnisnya.

\subsection{Pengendalian Internal}

Pengendalian internal meliputi struktur organsiasi, metode dan ukuran-ukuran yang dikoordinasikan untuk menjaga aset organisasi, mengecek ketelitian dan keandalan data akuntasi, mendorong efisiensi dan mendorong dipatuhinya kebijakan manajemen (Mulyadi, 2016:129). Menurut Valery G. Kumaat (2011:15) pengendalian internal adalah suatu cara untuk mengarahkan, mengawasi dan mengukur sumber daya suatu organisasi. Ia berperan penting untuk mencedah dan mendeteksi penggelapan (fraud) dan melindungi sumber daya organsiasi baik yang berwujud maupun tidak (seperti reputasi atau hak kekayaan intelektual seperti merek dagang). Sedangkan menurut Roney dan Steinbart (2005) pengendalian internal adalah rencana organsiaasi dan metode penggunaan bisnis untuk mengamankan aset, memberikan informasi yang akurat dan dapat diandalkan, mengembangkan operasional yang efisien dan mendorong kepatuhan untuk menjalankan kebijakan manajerial. Kemudian Niswonger Warren and Reeve Fees (2000:183) mendefisinikan pengendalian internal adalah kebijakan dan prosedur yang melindungi aset dari penyalahgunaan, memastikan bahwa informasi usaha akurat dan memastikan bahwa perundangundangan srta peraturan hukum dipatuhi sebagaimana mestinya.

Berdasarkan dari definisi yang dikemukakan tersebut maka dapat disimpulkan bahwa pengendalian internal adalan suatu proses yang dilaksanakan dalam kaitannya dengan kepastian terhadap semua alat-alat yang digunakan manajemen untuk mengadakan pengawasan, dapat berjalan sesuai dengan tujuan organisasi atau bisnis. 


\subsection{Zahir POSX}

Zahir Accounting adalah perusahaan pembuat dan pengembang piranti lunak akuntansi dengan nama Zahir Accounting sejak tahun 1996 yang dilahirkan oleh putra bangsa Indonesia. Zahir Accounting diberdayakan oleh tim terbaik dan inovator cerdas, meliputi programmer yang handal yang membuat produk hebat, tim implementasi yang berpengalaman membangun sistem di berbagai bisnis, dan staf dukungan pelanggan yang memberi pelayanan terbaik (Hutauruk, 2017:23). Zahir Accounting semakin inovatif di dalam menyikapi revolusi Industri 4.0. serta kebutuhan pebisnis di kelas UMKM, dan mampu melahirkan varian program yang terbarunya dengan nama Zahir POSX. Zahir POSX merupakan suatu aplikasi point of sale terbaru yang dikeluarkan oleh PT. Zahir International. Aplikasi POSX dapat di download dan digunakan secara gratis selama satu bulan pertama dan selanjutnya harus berbayar. Dengan adanya aplikasi ini pengusaha/pedagang kecil - menengah tidak perlu repot-repot membangun suatu sistem informasi yang mahal. Mereka cukup menggunakan sebuah smartphone, laptop dan printer, maka sudah dapat melakukan transaksi penjualan secara eletronik dan datanya dapat disimpan dalam database.

Aplikasi Zahir POSX ini merupakan salah satu solusi penting atas personal yang dihadapi pada pebisnis dalam kelompok UMKM. Melalui aplikasi Zahir POSX ini maka akan semakin mempermudah para pebisnis UMKM untuk mengelola bisnisnya secara lebih profesional dan berkelanjutan. Para pengguna program ini cukup hanya memiliki smartphone dan melakukan download secara free lalu memulai demo program yang telah disiapkan oleh provider. Pengguna program ini harus bersifat online sehingga data dan transaksi akan tersimpan secara otomatis di dunia maya atau virtual melalui cloud.

\subsection{Manajemen Bisnis}

Menurut Aldag dan Strearns (1995) manajemen adalah suatu proses perencanaan, pengorganisasian, dan pengelolaan staf, kepemimpinan, dan pengawasan dalam organisasi yang dilakukan secara sistematis guna mencapai tujuan tertentu. Menurut G.R. Terry (1997) manajemen adalah usaha-usaha untuk mencapai tujuan yang telah ditetapkan lebih dahulu dengan mempergunakan kegiatan orang lain. Selanjutnya menurut Stoner dan Freeman (2000) manajemen adalah proses dari perencanaan, pengorganisasian, pemimpin dan pengawasan pekerjaan anggotaanggota organisasi yang ada untuk mencapai tujuan organissi. Kemudian Gibson, Ivancevich dan Donnelly (2000) menyatakan bahwa manajemen adalah proses dari seseorang atau beberapa individu untuk mengkoordinasi kegiatan-kegiatan dari orang lain untuk memperoleh hasil yang tidak dapat dilakukan seseorang individu saja. Bisnis merupakan kegiatan yang dapat memberikan banyak keuntungan bagi kamu yang dapat memenejemen bisnisnya dengan baik. Rencana dalam berbisnis tentu menjadi poin penting yang sangat berperan dalam kesuksesan untuk para pebisnis. Terlepas dari status sebagai pemula atau senior, manajemen bisnis yang baik akan mampu membawa bisnis ke arah yang lebih baik juga. Selain itu ketahanan akan segala jenis tantangan dan hambatan juga bisa menjadi faktor penting dalam berjalannya bisnis Anda. strategi dalam berbisnis pun harus bisa disusun untuk bisa mengetahui tren di pasaran sehingga bisnis tetap bertahan.

Menurut Hughes dan Kapoor (1985) "Business is the organized effort of individuals to produce and sell for a profit, the goods and services that satisfy society's needs. The general term business refers to all such efforts withis a society or within an industry" (Bisnis adalah suatu kegiatan usaha individu yang terorganisasi untuk menghasilkan dan menjual barang dan jasa guna mendapatkan keuntugnan dalam memenuhi kebutuhan masyarakat. Secara umum kegiatan ini ada dalam masyarakat dan ada dalam indutri). Menurut Brown dan Petrello (1976) menyatakan "Business is an institution which produces good and services demanded by people" (Bisnis merupakan suatu lembaga yang menghasilkan barang dan jasa yang dibutuhkan oleh masyarakat, termasuk jasa dari pihak pemerintah dan swasta yang disediakan untuk melayani anggota masyarakat. 
Berdasarkan dari uraian tersebut maka dapat disimpulkan bahwa manajemen bisnis adalah proses dari perencanaan, pengorganisasian, pemimpin dan pengawasan pekerjaan anggota-anggota organisasi yang ada untuk mencapai tujuan bisnis organisasi. Mengingat rencana bisnis adalah seperti konsep pengembangan tertulis dalam bisnis, maka semua gambaran pengelolaan, manajemen, keuangan, pengembangan hingga target dan pemasarannya pun harus terencana secara sempurna. Jangan abaikan target pencapaian jangka pendek hingga jangka panjangnya sehingga hal ini bisa berpengaruh terhadap tata kelola dan manajemen bisnis yang akan dijalankan. Perencanaan secara keseluruhan dengan detil dan matang akan membuat gambaran dari bisnis bisa lebih tampak nyata yang membuat pebisnis lebih mudah dalam menjalankannya.

\subsection{Usaha Mikro Kecil dan Menengah (UMKM)}

Usaha Mikro, Kecil dan Menengah (UMKM) oleh para ekonom telah jamak dipahami sebagai tumpuan perekonomian sebuah negara. Tanpa adanya usaha kecil, roda perekonomian akan macet dan akan banyak memberikan dampak pada usaha skala besar. Selain itu, sifat dari usaha kecil yang mudah dan gesit membuat banyak ruang bagi pencari lowongan kerja. Itu sebabnya, perhatian pada usaha kecil menengah semakin besar dilakukan untuk menjaga kondisi ekonomi Indonesia.

Peran UMKM juga dikatakan mendominasi kontribusi terhadap Produk Domestik Bruto (PDB) dalam lima tahun terakhir. Berdasarkan data Kementerian Koperasi dan Usaha Kecil Menengah Republik Indonesia yang dikutip dari CNN Indonesia, disebutkan bahwa kontribusi UMKM meningkat cukup tinggi dari 57,84 persen menjadi 60,34 persen. Dari segi tenaga kerja, serapan tenaga kerja sektor usaha kecil juga meningkat dari 96,99 persen menjadi 97,22 persen. Hal ini membuktikan bahwa sektor UMKM menjadi tumpuan utama bagi ekonomi Indonesia. Tanpa adanya UMKM, tingkat pendapatan dan kemampuan beli masyarakat kecil tidak akan meningkat. Sehingga secara strategis UMKM memiliki peran dalam mengentaskan kemiskinan dan pengangguran. Di Indonesia, UMKM selain berperan dalam pertumbuhan pembangunan dan ekonomi, juga memiliki kontribusi yang penting dalam mengatasi masalah pengangguran (CNN Indonesia, Senin 21/11).

Bisnis UMKM memang memiliki beberapa kelemahan dalam beroperasi. Misalnya saja, kesulitan pemasaran, akses ke sumber pembiayaan yang sangat terbatas, keterbatasan sumber daya manusia (SDM), kesulitan bahan baku, keterbatasan inovasi dan teknologi. Upaya perbaikan dalam pengembangan UMKM ini seringkali hanya dijadikan komoditas politik meski cukup banyak Kementerian/Lembaga yang memberikan perhatian pada upaya meningkatkan kemampuan UMKM, sehingga pengembangan UMKM tidak optimal dilakukan.

Berdasarkan dari uraian tersebut maka dapat disimpulkan bahwa UMKM adalah jenis usaha kerakyatan Indonesia yang paling banyak terdapat di masyarakat dan mampu mengangkat tingkat ekonomi kerakyatan dan paling banyak menyerap tenaga kerja dari kalangan bawah tanpa harus memiliki keterampilan khusus, sehingga efektif mampu menyerap pengangguran dan perlu mendapatkan perhatian untuk dapat dioptimalkan.

\subsection{Pengaruh Penggunaan Software Zahir POSX Terhadap Manajemen Bisnis}

Dewasa ini kelangsungan sebuah bisnis ditentukan oleh kemampuan untuk bersaing. Agar mampu menhadapi persaingan di pasar, maka dibutuhkan strategi dengan memanfaatkan semua kekuatan dan peluang yang dimiliki, serta menghilangkan hambatan yang terjadi dalam bisnisnya. Menentukan strategi bisnis dapat dilakukan jika keputusan yang diambil berdasarkan masukan yang obyektif. Salah satu faktor yang digunakan sebagai landasan dalam pengambilan keputusan adalah berasal dari sistem akuntansi. Akuntansi merupakan proses mengidentifikasi, mengukut, dan melaporkan informasi eknomi untuk dilakukan keputausn yang jelas bagi mereka yang menggunakan informasi tersebut (zahiraccounting.com)

Penelitian yang dilakukan oleh Yuli Fauziah (2013) dengan penelitian berjudul "Aplikasi E- 
Services Barbasis Cloud Computing", di mana penelitian ini menyimpulkan bahwa pengujian fungsional membuktikan bahwa aplikasi e-service mampu melakukan pelayanan elektronik seperti membuat desain baru, menyimpan, mengubah/mengedit, dan membagikan ke pengguna lain. Pengujian kualitatif membuktikan bahwa aplikasi e-service ini kemudahan akses, kemudahan penggunaan, daya tarik, fitur-fitur, tampilan (interface) aplikasi rata-rata telah mendekati skala respon sangat baik. Secara garis besar aplikasi dokumen berbasis virtual ini telah dinyatakan layak digunakan untuk menunjang aktivitas setting desain grafis. Penelitian yang dilakukan oleh Mohammadi dan Mohammadi (2014) berjudul "Effect of Cloud Computing in Accounting and Comparison with the Traditional Model", di mana melalui penggunaan jaringan online atau dengan penggunaan server di cloud maka akan semakin memudahkan di dalam penyimpangan data yang relatif besar dan pemrosesan yang online. Adanya fasilitas cloud computing, maka layanan cloud dapat memudahkan para pelanggan untuk dapat menggunakannya secara mobile dan di mana saja. Dengan demikian komputer akuntansi melalui penggunaan cloud computing akan mampu meningkatkan efisiensi, efektivitas, akurat dan dapat dipercaya. Kondisi ini membuat pengelolaan bisnis akan semakin optimal. Penelitian yang dilakukan oleh Hutauruk, Suyanto dan Yulidar (2018) dengan judul "Pengaruh Program Zahir Accounting Versi 6 Terhadap Sistem Informasi Akuntansi Dan Sistem Pengendalian Internal Serta Sistem Informasi Keuangan Pada Usaha Mikro, Kecil Dan Menengah Di Kalimantan Timur”, di mana Zahir Accounting mampu berpengaruh terhadap pengelolaan bisnis pada UMKM di Kaltim.

\section{Hipotesis}

Berdasarkan dari penjelasan yang telah dikemukakan dalam studi ini maka dapat ditampilkan bagan gambar kerangka pikir dan hipotesis sebagai berikut:

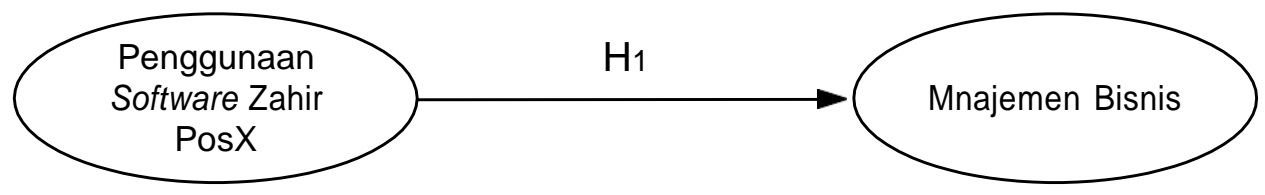

Gambar 1 Kerangka Konsep Penelitian

$\mathbf{H}_{\mathbf{1}}$ : Penggunaan software Zahir POSX mampu berpengaruh signifikan terhadap manajemen bisnis pengusaha UMKM di Samarinda.

\section{Metode Penelitian}

\subsection{Rancangan Penelitian}

Penelitian ini termasuk penelitian lapangan (Field Research), yaitu penelitian yang langsung dilakukan di lapangan atau pada responden (Iqbal Hasan, 2008). Penelitian ini menggunakan pendekatan kuantitatif, yaitu penelitian yang penyajian datanya berupa angka-angka dan menggunakan analisa statistik biasanya bertujuan untuk menunjukkan hubungan antara variabel, menguji teori dan mencari generalisasi yang mempunyai nilai prediksi (Sugiyono, 2006). Datadata yang dikumpulkan dalam penelitian ini adalah bersumber dari data primer dengan media kuesioner. Penelitian ini menggunakan pendekatan metode survei. Metode survei yaitu metode yang mengambil contoh data dari satu populasi dan menggunakan kuesioner sebagai alat pengumpulan data yang pokok (Singarimbun dan Effendi, 1989). Dengan menggunakan pendekatan kuantitatif diharapkan adanya pemahaman mengenai penggunaan software Zahir POSX terhadap manajemen bisnis UMKM di Samarinda, khususnya di sekitar lokasi Universitas Widya Gama Mahakam Samarinda. 
Secara umum jenis penelitian ini adalah penelitian asosiatif atau penelitian yang berusaha mencari hubungan antara satu variabel dengan variabel lain. Hubungannya bisa simetris, atau interaktif. Teknik analisis penelitian asosiatif ini menggunakan teknik analisis kuantitatif atau statistik. Perhitungan untuk mengetahui hubungan dan pengaruh antar variabel itu antara lain perhitungan koefisien korelasi.

\subsection{Uji Instrumen Penelitian}

Pengujian validitas dan reliabilitas instrumen dilakukan berdasarkan data hasil ujicoba. Uji coba dilakukan terhadap 163 responden untuk variabel Software Zahir POSX dan variabel Manajemen Bisnis. Uji validitas yang dimaksudkan untuk menanyakan serangkaian pertanyaan dengan harapan bahwa pertanyaan tersebut menyentuh konsep dan yakin bahwa peneliti mengukur konsep yang disiapkan dan bukan yang lain. Beberapa bentuk uji validitas dikelompokkan menjadi : content validity, criterion-related validity dan construct validity. Uji reliabilitas dilakukan dengan tujuan untuk mengetahui konsistensi data yang diperoleh.

Uji reliabilitas yang digunakan di dalam penelitian ini adalah validitas konstruk masing-masing item (indikator) dikatakan valid jika hipotesis terhadap loading factor bersifat signifikan ( $p$-value $<0,05)$. Uji reliabilitas yang digunakan di dalam penelitian ini adalah Composite reliability (pc). Instrumen penelitian untuk mengukur sebuah variabel memiliki reliabilitas komposit yang baik jika memiliki composite reliability $\geq 0.7$, walaupun bukan merupakan standar absolut.

\section{4,3 Populasi dan Sampel}

Populasi penelitian ini adalah pengusahan dalam bidang jasa, dagang dan manufaktur ringan dan termasuk ke dalam UMKM yang berlokasi Samarinda, atau tepatnya yang berjualan di sekitar Universitas Mulawarman dan wilayah Universitas Widya Gama Mahakam Samarinda, dengan jumlah pengusaha seluruhnya sebanyak 275 pengusaha UMKM. Penelitian ini menggunakan metode proposional random sample dengan mengambil jumlah sampel dari populasi tertentu yang diambil dari keseluruhan jumlah responden pengusaha kelompok UMKM, dan untuk menentukan sampel digunakan dengan pendekatan atau konsep Slovin dengan tingkat error 5\% diperoleh sampel sebanyak 163 responden dan dilakukan pengedaran kueseioner.

\subsection{Teknik Analisis Data}

Estimasi parameter yang didapat dengan PLS dapat dikategorikan menjadi tiga. Kategori pertama adalah weight estimate yang digunakan untuk menciptakan skor variabel laten. Kedua mencerminkan estimasi jalur (path estimate) yang menghubungkan variabel laten dan antar variabel laten dan blok indikatornya (loading). Kategori ketiga adalah berkaitan dengan means dan lokasi parameter (nilai konstanta regresi) untuk indikator dan variabel laten. Untuk memperoleh ketiga estimasi ini, PLS menggunakan proses iterasi tiga tahap dan setiap tahap iterasi menghasilkan estimasi. Tahap pertama menghasilkan weight estimate, tahap kedua menghasilkan estimasi untuk inner model dan outer model dan tahap ketiga menghasilkan estimasi means dan lokasi (konstanta) (Ghozali, 2011: 19).

Secara umum model spesifikasi dengan PLS dapat dikemukakan dengan model analisis jalur semua variabel laten terdiri dari tiga set hubungan: (1) inner model yang menspesifiikasikan hubungan antar variabel laten (structural model), (2) outer model yang menspesifikasi hubungan antara variabel laten dengan indikator atau variabel manifestnya (measurement model), dan (3) weight relation dalam mana nilai kasus dan variabel laten dapat diestimasi. Tanpa kehilangan generalisasi dapat diasumsikan bahwa variabel laten dan indikator atau manifest diskala zero means dan unit variance (nilai standardized) sehingga parameter lokasi (parameter konstanta) dapat dihilangkan dalam model. Tahapan penggunaan PLS-SEM melalui lima proses tahapan di mana setiap tahapan akan berpengaruh terhadap tahapan selanjutnya, yaitu: (1) konseptual model, 
(2) menentukan metoda analisis algorith, (3) menentukan metoda resampling, (4) menggambar diagram jalur dan (5) evaluasi model, serta (6) melaporkan hasil analisis PLS dan digambarkan sebagai berikut (Ghozali dan Latan, 2014:53).

\section{Hasil Penelitian}

Penelitian ini telah melalui proses uji validitas dan reliabilitas dan menunjukkan bahwa pengujian validitas dan reliabilitas di dalam penelitian ini dilakukan dengan cara One Shot atau dengan sekali ukur atau sering disebut pula dengan pengujian internal consistency untuk mengefisiensikan waktu, tenaga dan biaya penelitian. Sehubungan dengan penelitian yang dilakukan maka dibuat butir pertanyaan sehubungan dengan seluruh jenis variabel yang digunakan, yang seluruhnya berjumlah 2 variabel dan seluruhnya menghasilkan 14 butir pertanyaan yang disebarkan kepada 163 responden.

Berdasarkan dari hasil uji validitas metode Corrected Item-total Correlation yang telah dilakukan, maka didapatkan ada lima output dari yang pertama adalah Software Zahir POSX (SZPX) dan yang kedua adalah Manajemen Bisnis (MJNB). Pada output tersebut didapatkan bahwa nilai korelasi antara tiap butir pertanyaan dengan skor total butir pertanyaan sudah dikoreksi. Nilai korelasi ini dibandingkan dengan $r$ tabel. $\mathrm{R}$ tabel pada signifikansi 0,05 dengan uji 2 sisi dan jumlah data $(\mathrm{n}-2)=163-2$ atau df 161 , maka didapat nilai $\mathrm{r}$ tabel untuk uji 2 arah sebesar 0,2012 . Untuk seluruh butir pertanyaan mulai dari kelompok SZPX (SZPX1, SZPX2, SZPX3, SZPX4, SZPX5, SZPX6, dan SZPX7) tidak terdapat nilai Corrected Itemtotal Correlation yang memiliki nilai di bawah atau $<$ dari 0,2012 , di mana seluruhnya menghasilkan nilai di atas > 0,2012 dan menunjukkan hasil data atau butir pertanyaan yang valid seluruhnya (Nunnaly J. dan Berstein, IH, 1994).

Berdasarkan dari uji reliabilitas menunjukkan bahwa seluruh butir-butor pertanyaan bernilai Cronbach Alpha di atas atau > 0,70 yang menunjukkan bahwa seluruhnya reliabel. Artinya hasil tersebut menunjukkan bahwa nilai Cronbach's Alpha atas dua puluh lima butir pertanyaan tersebut seluruhnya berada di atas atau >0,70, maka dapat disimpulkan bahwa alat ukur di dalam penelitian ini telah reliabel seluruhnya atau alat pengukur dalam penelitian ini adalah tergolong baik dan dapat digunakan seluruhnya (Nunnaly J. dan Berstein, IH, 1994).

Evaluasi Outer Model Konstruk Refleksif dengan Loading Factor Indikator variabel software zahir POSX merefleksikan indikator MNRK, MDAH, BELI, JUAL, SDIA, KASIR dan MBII. Nilai loadings untuk setiap indikator customer solution dapat dilihat pada Tabel 1 sebagai berikut:

Tabel 1 Outer Loadings Indikator Variabel Software Zahir POSX

\begin{tabular}{|c|c|c|}
\hline Indikator & Outer Loadings & $\begin{array}{c}\text { T-Statistic } \\
\text { (t ktirits: 1.96) }\end{array}$ \\
\hline MNRK & 0,8004 & 24,9305 \\
\hline MDAH & 0,7770 & 19,9081 \\
\hline BELI & 0,8347 & 30,6111 \\
\hline JUAL & 0,8082 & 19,9544 \\
\hline SDIA & 0,7815 & 25,5381 \\
\hline KSIR & 0,7124 & 16,7229 \\
\hline MBIL & 0,7398 & 16,4845 \\
\hline
\end{tabular}

Sumber: Data diolah, 2019

Indikator variabel customer cost direfleksikan oleh PRSL, ASST, LPRN, PMSK, BSNS, ONLN, dan ANDL. Nilai loadings untuk setiap indikator customer cost dapat dilihat pada Tabel 5.6 sebagai berikut: 
Tabel 2 Outer L:oadings Indikator Vavariabel Manajemen Bisnis

\begin{tabular}{|c|c|c|}
\hline Indikator & Outer Loadings & $\begin{array}{c}\text { T-Statistic } \\
\text { (t ktirits: } \mathbf{1 . 9 6})\end{array}$ \\
\hline PRSL & 0,7010 & 15,6375 \\
\hline ASST & 0,8039 & 24,8859 \\
\hline LPRN & 0,7607 & 18,3135 \\
\hline PMSK & 0,7838 & 24,0927 \\
\hline BSNS & 0,7987 & 21,8141 \\
\hline ONLN & 0,7745 & 22,0092 \\
\hline ANDL & 0,6969 & 14,9342 \\
\hline
\end{tabular}

Sumber: Data diolah, 2019

Pada Tabel 2 tersebut memperlihatkan bahwa outer loadings yang terbesar hingga ke yang terkecil adalah dengan urutan ASST, PMSK, ONLN, BSNS, LPRN, PRSL, dan ANDL sehingga hal ini menunjukkan pula urutan yang dominan indikator dalam merefleksikan variabel manajemen bisnis.

\section{Evaluasi Nilai Average Variance Extracted (AVE)}

Adapun untuk melihat validitas dan realibailitas pada model strukturual dalam konstruk refleksif, maka dapat dilihat dalam nilai AVE seperti dalam Tabel 3 sebagai berikut:

Tabel 3 Nilai Average Variance Extracted (AVE) dan Composite Reliability

\begin{tabular}{|l|c|c|}
\hline & $\begin{array}{c}\text { Average Variance Extracted } \\
\text { (AVE) }\end{array}$ & Compisite Realibility \\
\hline Software Zahir POSX & 0.5792 & 0.9156 \\
\hline Manajemen Bisnis & 0.6085 & 0.9068 \\
\hline
\end{tabular}

Sumber: Data diolah, 2019

Berdasarkan nilai AVE yang dihasilkan oleh semua atau seluruh konstruk refleksif yaitu di atas > 0.50 sehingga telah memenuhi persyaratan validitas konvergen dan reliabilitas. Berdasarkan nilai Composite Reliability yang dihasilkan oleh semua konstruk refleksif yaitu di atas $>0.70$ sehingga dapat disimpulkan bahwa semua indikator konstruk refleksif adalah reliabel atau memenuhi uji reliabilitas.

\section{Evaluasi Inner Model}

Evaluasi terhadap inner model pada penelitian ini adalah dapat dilihat ke dalam Tabel 4 sebagai berikut:

Tabel 4 Evaluasi Nilai $R$ Square dan RSquare Adjusted

\begin{tabular}{|c|c|c|}
\hline & R Square & $\boldsymbol{R}$ Square Adjusted \\
\hline Manajemen Bisnis & 0,1684 & 0,1633 \\
\hline
\end{tabular}

Sumber: Data diolah, 2019 
Berdasarkan dari Tabel 4 tersebut maka dapat diketahui pengujian terhadap structural dilakukan dengan melihat nilai R-square yang merupakan uji goodness-fit model. Model pengaruh Penggunaan Software Zahir POSX terhadap Manajemen Bisnis memberikan nilai 0,1684 yang dapat diinterpretasikan bahwa variabel konstruk Manajemen Bisnis dapat dijelaskan oleh variabilitas konstruk Penggunaan Software Zahir POSX sebesar 16,84\% sedangkan 83,16\% dijelaskan oleh variabel lain di luar yang diteliti termasuk faktor error. Adapun signifikansi pengaruh Penggunaan Software Zahir POSX terhadap Manajemen Bisnis. Semakin tinggi Penggunaan Software Zahir POSX maka semakin tinggi Manajemen Bisnis, dengan nilai t statistik sebesar 6,6329 signifikan ( $\mathrm{t}$ tabel signifikansi 5\% - 1,96) oleh karena $\mathrm{t}$ statistik lebih besar dari t tabel 1,96.

\section{Hasil Analisis Jalur: Pengujian Hipotesis}

Hasil analisis jalur dapat disajikan berdasarkan hasil penelitian ini dan pengujian hipotesis penelitian ini dilakukan dengan melihat jalur-jalur pada model struktural yang signifikan. Jalurjalur hubungan dan pengaruh yang signifikan dapat dilihat pada uji koefisien jalur secara parsial, menggunakan uji t ( $t$-test), atau dengan melihat tingkat signifikansinya. Hasil uji secara parsial terhadap koefisien jalur pada setiap jalur dengan berdasarkan nilai loading atau kofisien dapat dilihat pada Gambar 1 sebagai berikut:

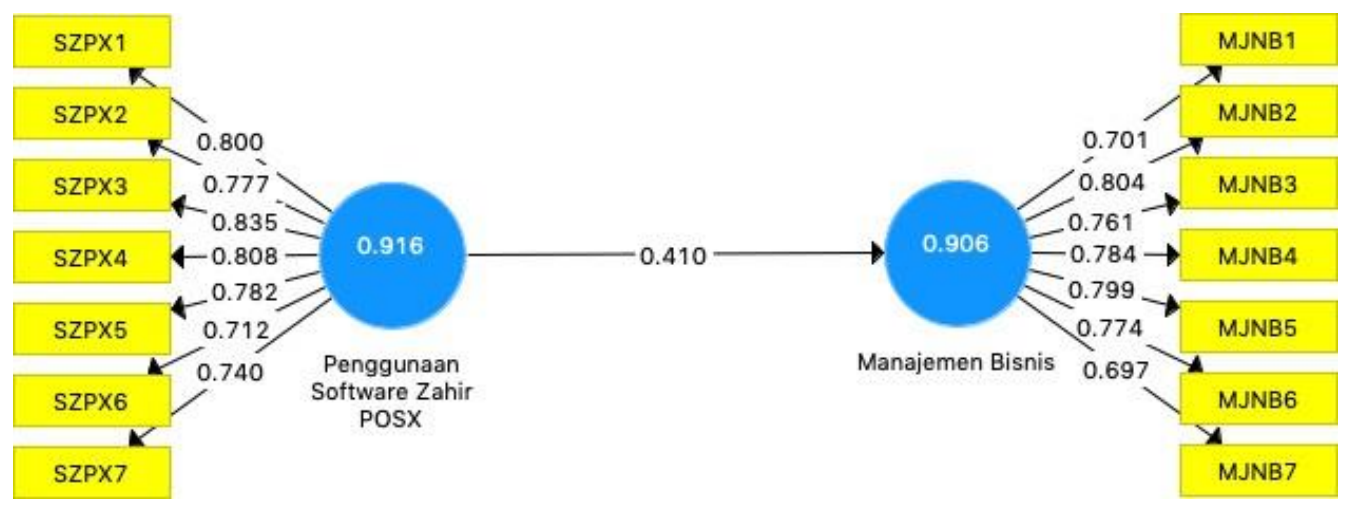

Sumber: Data diolah, 2019

\section{Gambar 1 Model Struktural Analisis Jalur Dengan Nilai Loading}

Hasil uji secara parsial terhadap koefisien jalur pada setiap jalur pada setiap jalur dengan berdasarkan nilai signifikansi dengan metode resampling (Bootstrapping) dapat dilihat pada Gambar 2 sebagai berikut:

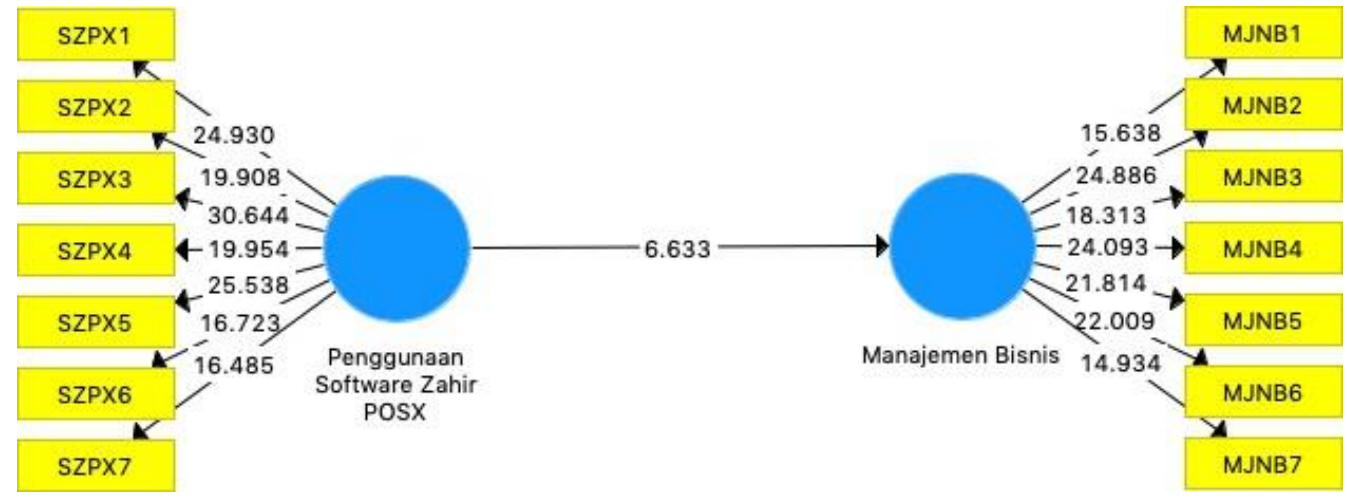

Sumber: Data diolah, 2019

Gambar 2 Model Struktural Analisis Jalur Dengan Resampling 
Berdasarkan dari hasil analisis pada Gambar 1 dan 2 tersebut, maka dapat dianalisis selanjutnya dengan menampilkan pengaruh langsung variabel eksogen ke variabel endogen ke dalam Tabel 5 sebagai berikut:

Tabel 5 Pengaruh Langsung Antar Variabel

\begin{tabular}{|l|c|c|c|c|c|}
\hline & $\begin{array}{c}\text { Original } \\
\text { Sample (O) }\end{array}$ & $\begin{array}{c}\text { Sample } \\
\text { Mean } \\
(\mathbf{M})\end{array}$ & $\begin{array}{c}\text { Standard } \\
\text { Deviation } \\
\text { (STDEV) }\end{array}$ & $\begin{array}{c}\text { T Statistics } \\
(\mid \mathbf{O} / \text { STERR|) }\end{array}$ & $\begin{array}{c}\text { P } \\
\text { values }\end{array}$ \\
\hline $\begin{array}{l}\text { Penggunaan Software Zahir } \\
\text { POSX -> Manajemen } \\
\text { Bisnis }\end{array}$ & 0.4104 & 0.4290 & 0.0619 & 6.6329 & 0.000 \\
\hline
\end{tabular}

Sumber: Data diolah, 2019

Pada Tabel 5 tersebut menunjukkan bahwa Penggunaan Software Zahir POSX berpengaruh langsung secara positif dan signifikan terhadap Manajemen Bisnis atau dengan nilai T Statistik 6,6329 > 1,96 atau dengan nilai $\mathrm{P}$ values 0,000. Berdasarkan dari uraian tersebut, maka dapat disimpulkan bahwa permasalahan yang dikemukakan pada bagian awal studi ini dapat terjawab dan hipotesis yang dikemukakan pula diuji kebenarannya.

Hasil uji hipotesis yang telah dilakukan berdasrakan pada Gambar 1, 2 dan Tabel 5 dapat disajikan hasil pengujian hipotesis sebagai berikut:

1. Hipotesis 1: T-Statistik 6,6329 > 1,96 atau sig. 0,000 > 1,96 yang menunjukkan bahwa hipotesis statistik $\mathrm{H}_{0}$ ditolak dan $\mathrm{H}_{1}$ diterima atau di mana Pengunaan Software Zahir POSX berpengaruh signifikan terhadap Manajemen Bsinis pada kelompok UMKM yang ada di sekitar kampus Univeresitas Widya Gama Mahakam Samarinda.

\section{Pengaruh Penggunaan Software Zahir POSX Terhadap Manajemen Bisnis Pada Usaha Mikro, Kecil dan Menengah (UMKM) yang Berada di Sekitar Lokasi Universitas Widyagama Samarinda dan Universitas Mulawarman Samarinda.}

Berdasarkan Tabel 1 Outer Loadings indikator variabel Penggunaan Software Zahir POSX dan Gambar 1 Model Struktural Analisis Jalur dengan Nilai Loadings serta Gambar 2 Model Struktural analisis Jalur dengan Resampling, maka dapat diketahui bahwa mengelola transaksi pembelian dengan baik dan memonitor aset perusahaan setiap waktu, adalah merupakan indikator yang dominan sebagai pengukur variabel Manajemen Bisnis. Dalam hal ini, nilai indikator variabel memiliki arah positif yang menunjukkan bahwa semakin tinggi pengelolaan transaksi pembelian, mengelola persediaan dengan baik, tampilan program yang menarik, mengelola transaksi penjualan dengan baik, mudah dalam penggunaan, mengelola kas dengan baik, dan transaksi secara mobile, maka akan semakin tinggi pula nilai Manajemen Bisnis.

Hasil analisis menunjukkan bahwa koefisien jalur pengaruh langsung penggunaan software Zahir POSX terhadap manajemen bisnis diperoleh nilai koefisien jalur sebesar 0,4104 dan pada t-statistik 6,6329 serta nilai p-values 0,000. Hasil tersebut menunjukkan bahwa terdapat cukup bukti secara statistik untuk menerima hipotesis 1 (H1) bahwa Penggunaan Software Zahir POSX berpengaruh signifikan terhadap Manajemen Bisnis pada pengusaha UMKM yang berada di sekitar Universitas Widya Gama Mahakam Samarinda dan Universitas Mulawarman Samarinda. Hal tersebut juga dapat dikonfirmasi pada Gambar 5.1 Model Analisis Struktural dengan Nilai Loadings dan Gambar 5.2 Model struktural dengan metode resampling serta pada Tabel 5.10 Pengaruh langsung antar variabel. 
Temuan ini juga menunjukkan bahwa dengan adanya pengelolaan transaksi pembelian dengan baik sebagai indikator yang dominan pada Penggunaan Software Zahir POSX mampu bertindak sebagai salah satu hal atau alasan bagi pengusaha UMKM dalam memilih dan menggunakan software akuntansi sederhana dan pengelolaan bisnis dengan lebih baik.

Hasil penelitian ini juga sejalan dengan pendapat yang dikemukakan oleh American Asociation Accounting (1966) di mana kegiatan akuntansi adalah proses menggali, mengukur, dan mengkomunikasikan informasi ekonomi untuk memperoleh pertimbangan dan keputusan yang tepat oleh pemakain informasi ekonomi yang bersangkutan. Sejalan pula dengan pendapat Hutauruk (2017), di mana akuntansi adalah merupakan kumpulan konsep dan teknik yang digunakan untuk mengukur dan melaporkan informasi keuangan dan bisnis. Demikian pula halnya sejalan dengan pendapat Horngren, Horison dan Suardy (2013) di mana kegiatan akuntansi adalah suatu sisten informasi yang mengukur aktivitas bisnis, memproses data menjadi laporan dan mengkomunikasikan hasilnya kepada para pengambil keputusan. Demikian pula sejalan dengan pendapat Mulyadi (2001), Kumaat (2011), Roney and Steinbart (2005), Warren and Fees (2000), di mana pengendalian internal adalah merupakan kebijakan dan prosedur yang dilakukan untuk melindungi aset dari penyalahgunaan, memastikan bahwa informasi yang disajikan adalah akurat dan dapat dipertanggungjawabkan.

Hasil temuan studi ini juga mampu mengkonfirmasi kajian empiris yang dilakukan oleh Fauziah (2013), di mana melalui pengujian fungsional membuktikan bahwa aplikasi e-service mampu melakukan pelayanan elektroni seperti membuat desain baru, menyimpan, mengedit dan membagikan kepada pengguna lainnya. Sejalan pula dengan hasil temuan Mohammadi dan Mohammadi (2014) di mana melalui penggunaan jaringan online atau dengan penggunaan server di cloud maka akan semakin memudahkan di dalam penyimpangan data yang relatif besar dan pemrosesan yang online. Hasil temuan penelitian ini juga sejalan dengan hasil temuan Hutauruk, Suyanto dan Yulidar (2018) di mana Zahir Accounting mampu berpengaruh terhadap pengelolaan bisnis pada UMKM di Kaltim.

Hasil temuan penelitian ini mampu menunjukkan pula bahwa software Zahir POSX sebagai salah satu alternatif software akuntansi yang sederhana yang terdapat di Indonesia dan Asia, mampu menjadi jembatan yang baik di dalam menjembatani antara kebutuhan administrasi pengusaha UMKM dan pengelolaan bisnis yang baik. Terlihat pula bahwa pengusaha UMKM yang ada di lokasi penelitian tidak dapat terlepas pada sistem persediaan. Sistem persediaan ini sangat dibutuhkan, baik jenis bisnis jasa, perdagangan dan manufaktur ringan. Melalui pesediaan, maka akan ditentukan sifat persediaan tersebut, baik yang bertujuan untuk pendukung kegiatan sebagai bahan habis pakai, dibeli dan disimpan kemudian dijual kembali ataupun digunakan sebagian atau seluruhnya untuk proses produksi yang lebih lanjut.

Adanya software akuntansi yang sederhan ini akan mampu memotong aliran bisnis yang rumit dan panjang menjadi lebih sederhana dan mudah dipahami bagi siapa saja. Selain itu sistem pengendalian internal yang lebih baik akan dapat dijalankan dengan mudah.

Kemajuan teknologi dan informasi membuat semakin maraknya perangkat elektronik berbasis data yang tersedia di pasaran dengan harga yang terjangkau bagi siapa saja, yang dapat dilihat dalam wujud smart handphone. Beberapa provider program akuntansi telah mendesain dengan sangat modern dan memasarkan produk mereka dalam bentuk software akuntansi sederhana hingga terlengkap. Zahir POSX adalah salah satu software akuntansi sederhana yang sangat cocok dan mampu mengatasi persoalan administrasi bisnis UMKM. Pengguna tidak perlu harus memiliki pengetahuan dan pengalaman akuntansi yang terlalu dalam, namun dapat dengan cepat menyesuaikan diri terhadap software yang telah dirancang khusus ini.

Hasil pengamatan yang telah dilakukan di lapangan, membuktikan bahwa hipptesis yang dikemukakan dapat terjawab dengan baik. Pengusaha UMKM mampu mengaplikasikan dengan baik ke dalam perangkat smartphone mereka dan gadget lainnya melalui tmapilan proram yang dinamis. Mereka mampu memonitoring pembelian dan penyimpanan serta pembentukan harganya dengan baik. Transaksi pembayaran dan penerimaan uang tunai pun dapat dilakukan dengan sekali 
jalan dalam genggaman handphone. Selain itu proses bisnis dapat dipantau setiap saat dan di mana saja sambal melakukan proses berjualan. Akhir proses atau kegiatan bisnis dapat diketahui kesimpulannya secara per hari oleh pengusaha UMKM.

Penggunaan software Zahir POSX ini mampu menimngkatkan kemampuan pengelolaan bisnis dengan lebih baik, tepat waktu, akurat serta dapat dipercaya kebenarannya. Hasil penggunaan program ini mampu memberikan informasi bisnis secara up to date dan kapan saja serta di mana saja. Kantor mobile dalam satu genggaman, inilah yang dapat dikatakan secara umum atas penggunaan program ini yang dengan setia mendapingi pengusaha.

\section{Kesimpulan}

Berdasarkan dari hasil analisis yang pembahasan yang dilakukan, maka dapat disimpulkan bahwa penggunaan software Zahir POSX adalah berpengaruh secara langsung positif dan signifikan terhadap manajemen bisnis pada bisnis UMKM yang ada di di sekitar Universitas Mulawarman Samarinda dan Universitas Widya Gama Mahakam Samarinda.

Berdasarkan dari kesimpulan yang dikemukakan tersebut, maka dapat dikemukakam saran bahwa program akuntansi sederhana dalam wujud software Zahir POSX sangat baik digunakan serta patut dicoba pada kelompok pengusaha UMKM lainnya, karena mudah digunakan, menggunakan prinsip akuntansi yang baik dan mudah digunakan bagi siapa saja melalui sarana gadget yang ada.

Software Zahir POSX ini wajib dicoba oleh pebisnis UMKM yang lainnya, karena tersedia versi demo yang tidak berbayar, untuk dicoba. Para pebisnis akan menjadi lebih baik dalam adminitrasi dan dalam hal laporan aktivitas harian dapat terpantau dengan baik dan semakin mampu menekan risiko bisnis.

\section{Daftar Pustaka}

Adi, M. Kwartono. 2007. Analisis Usaha Kecil dan Menengah, Andi Offset, Yogyakarta.

Aldag, Ramon J dan Tomothy Streans. 2000. Management. Shouth Western Publishing Co. Chicago.

Baridwan, Zaki. 2004. Intermediate Accounting “Pengantar Akuntansi, Buku 2, Edisi 21. Salemba Empat. Jakarta.

Brown, R. D. dan G. J. Petrello.1976. Introduction to Business, An Integration Approach. GGlen Coe Press. Beverly Hills.

Djarwanto. 2010. Pokok-Pokok Analisis Laporan Keuangan. BPFE Yogyakarta.

Fees, P. E., Reeve, J. M., Warren, C. S., \& Niswonger, C. R. 1999. Prinsip - prinsip akuntansi jilid 1 (edisi 19). (alih bahasa Sirait, A., Gunawan, H.). Penerbit Erlangga. Jakarta.

Ghozali, Imam dan Latan, Hengky. 2014. Partial Least Squares Konsep, Metode Dan Aplikasi Menggunakan Program WarpPLS 4.0, Fakultas Ekonomika dan Bisnis Universitas Diponegoro, Semarang.

Ghozali, Iman dan Latan, hengky. 2015. Partial Least Squares Konsep, Teknik Dan Aplikasi Menggunakan Program SmartPLS 3.0 Untuk Penelitian Empiris, Badan Penerbit Universitas Diponegoro, Semarang.

Gibson, James L, John M. Ivancevich dan James H. Donnelly Jr, 2000. Organizations: Behaviour, Structure and Process, McGraw-Hill Companies Inc, Boston.

Gordon, B. Davis. 1991. Kerangka Dasar Sistem Informasi Manajemen Bagian 1, PT. Pustaka Binamas Pressindo. Jakarta. 
Hans K, Rosita U.S, Merliyana S. dan Sylvia V.S. Akuntansi Keuangan, Berdasarkan SAK Berbasis IFRS, Penerbit Salemba Empat, Jakarta.

Harrison Jr Wlater T., Horngren, C Wiliam Thomas, Suwardy T. 2013. Akuntansi Keuangan-Edisi IFRS, Edisi Kedepalan, Jilid 2, Erlangga, Jakarta.

Hughes, R.J. \& Kapoor, J.R. 1985. Business. Houghton Mifflin. U.S.A.

Husein, Umar. 2008. Metode Penelitian Untuk Skripsi dan Tesis Bisnis. Rajagrafindo Persada. Jakarta.

Hutauruk, Martinus Robert. 2017. Akuntansi Perusahaan Jasa. Aplikasi Program Zahir Accounting Versi 6. Indeks. Jakarta. . 2017. Akuntansi Perusahaan Dagang. Aplikasi Program Zahir Accounting Versi 6. STIM YKPN. Yogyakarta.

. 2019. Akuntansi Entitas Manufaktur, Kponsep, Teknik Dan Aplikasi Menggunakan Program Zahir Accounting 6STIM YKPN. Yogyakarta.

Hutauruk, Martinus Robert, Suyanto dan M. Astri Yulidar Abbas. 2018. Pengaruh Program Zahir Accounting Vesi 6 Terhadap Sistem Informasi Akuntansi Dan Sistem Pengendalian Internal, Serta Sistem Informasi Keuangan Pada Usaha Mikro Kecil dan Menengah Di Kalimantan Timur. Seminastika, Balikpapan, pp.245-255.

Ina Primiana. 2009. Menggerakkan Sektor Riil UKM dan Indusri. Alfabeta. Bandung.

James A.F. Stoner dan Freeman. 2000. Manajemen. Prenhalindo. Jakarta

L. Zhang and W. Gu, The Simple Analysis of Impact on Financial Outsourcing Because of The Rising Of Cloud Accounting, Asian Journal of Business and Management, 5(1) ,2013, 140143.

Machfoedz, Mas’ud dan Mahmudi. 2008. Materi Pokok Akuntansi Manajemen, Universitas Terbuka, Jakarta.

Mulyadi. 2001. Sistem Akuntansi, Edisi Tiga, Salemba Empat. Jakarta. . 2016. Sistem Akuntansi. Salemba Empat. Jakarta.

Nash, John F. 1995. Pengertian Sistem Informasi, Informatika. Jakarta.

Nunnally, J.C., and Bernstein, I.H. 1994. Psychometric Theory ( ${ }^{\text {rd }}$ ed), McGraw-Hill, New York.

O. Dimitriu and M. Matei, Cloud accounting: A new business model in a challenging context, Procedia Economics and Finance, 32,2015, 665-671.

Rommey, Marshall B dan Steinbart, Paul John. 2005. Accounting Information System, Edisi 9, Salemba Empat. Jakarta.

Rujito. 2003. Strategi Pembangan UMKM Berbasis Strategi Bisnis. Makalah Yang Disampaikan Pada Seminar Peran Perbankan Dalam Memperkokoh Ketahanan Nasional. Kerjasama Lemhanas RI Dengan BRI.

Shaban Mohammadi and Ali Mohammadi. 2014. Effect of Cloud Compiuting in Accounting and Comparison with the Traditional Model. Research Journal of Finance and Accounting. Vol5, No.23, pp. $104-114$.

Terry, George R. 1997. Prinsip-Prinsip Manajemen. Bumi Aksara. Jakarta

Valery G Kumaat. 2011. Internal Audit. Penerbit Erlangga. Jakarta.

Widjajanto, Nugroho. 2001. Sistem Informasi Akuntansi. Erlangga. Jakarta 
Yuli Fauziah. 2013. Aplikasi E-Services Berbais Cloud Computing. Seminar Nasional Informatika, (semnasIF) UPN "Veteran" Yogyakarta, pp29-35.

https://www.zahironline.com/en/home/

https://zahiraccounting.com/id/produk-new

https://play.google.com/store/apps/details?id=com.posx\&hl=en

https://zahiraccounting.com/id/produk/zahir-pos

https://www.cnnindonesia.com/ekonomi/20161121122525-92-174080/kontribusi-umkmterhadap-pdb-tembus-lebih-dari-60-persen? 